\title{
Interdisciplinary Approaches in \\ Pacific Studies: Understanding the \\ Fiji Coup of I9 May 2000
}

Vilsoni Hereniko

Reading most analyses of the events surrounding the Fiji coup of I9 May 2000 , I have been struck by their tone of "objectivity," as if human beings were robots created to obey agreed-on rules of behavior as laid out in a constitution. The actions of George Speight and his group of rebels who stormed the Fiji parliament and took hostage the members of a democratically elected government are usually portrayed as an affront to a precious document that is sacrosanct. Absent from these accounts is the human element, the emotional and irrational impulses that drive human action and behavior. For a better understanding of the events of ig May 2000 , I advocate an interdisciplinary approach. The term interdisciplinary does not mean multidisciplinary, which is often taken to mean addressing a problem or theme from two or three different disciplinary perspectives. Instead, the type of interdisciplinarity I advocate is an integrated approach, marked by the following characteristics: first, it puts culture and people at the center; second, it takes into account fiction as well as fact, the irrational as well as the rational; third, it gives voice to the underrepresented; fourth, it draws from sources that cut across the boundaries of disciplines; and finally, it is always open and questioning, rather than closed and final. By modeling the form and content of such an approach, I hope to better understand the nature of interdisciplinary work. A second goal is to see how this approach can provide insights that are not readily available when the boundaries of disciplines confine and constrain a point of view.

The Contemporary Pacific, Volume I5, Number I, Spring 2003, 75-90

(C) 2003 by University of Hawai ${ }^{i}$ Press 
For two years in the early I970s, I was a student at Fiji's Queen Victoria School (Qvs). This school had, and still has, a student body of about 300 Fijian males. Set up when Fiji was still a British colony, Queen Victoria was originally intended as a school where the sons of chiefs would be groomed for leadership. By the early I970s, good grades had become another password that could open the QVs doors. Apart from the 292 Fijians, there were six Rotumans, one Indian (the son of a shopkeeper living near the school), and one white female (the daughter of one of the teachers from New Zealand).

Having spent the first sixteen years of my life on Rotuma, I found boarding school at Queen Victoria a difficult adjustment, to say the least. Those two years of my life were miserable: I hated cadet or military training. Every Friday afternoon I would find some excuse to work in the library so I didn't have to march in platoons wearing a green beret, wielding a rifle, and shouting, "Order arms! Present arms!" Several Fijian boys also hated cadet training, and we formed a close bond.

When I left for the University of the South Pacific (USP) in I973, my close friends from Queen Victoria School joined me as well. I had my first real encounter with Indians in Fiji during my time at the university. Before long, I became very close friends with several of them. At the dining hall there were two lines, one for the Fijians and other Islanders and one for the Indians. I almost always preferred to be in the Indian line because I had developed a taste for Fiji's famous roti and curry. But I was always caught trying to sneak in and chased away to where I supposedly belonged. Similarly, one of my Indian friends preferred fish in coconut cream (lolo) and faced the same problem. It didn't take me long to realize that the way around this senseless separation into ethnic groups was to go to the dining hall with an Indian friend. That way, after we had been served, we could swap plates.

To my dismay, my Fijian friends who had transferred with me from Queen Victoria started to distance themselves from me. When I asked them why, they said that I was becoming too friendly with the Indians. Before long, they gave me what they called "rake." To "rake" means to act as though your enemy doesn't exist: you don't notice them, you don't talk to them anymore. This is the ultimate form of rejection: it's worse than being punched in the face because when you become the object of "rake," you have no way of dealing with the problem; all lines of communication have shut down. I still remember the hurt of being rejected by my Fijian friends, because in their eyes, I had defected to the enemy's camp. 
After five years at the University of the South Pacific, I returned to Queen Victoria School to teach English and history. I taught at this school for four wonderful years, and they made up for the two bad years I had spent there as a student. I discovered that as a teacher I could influence what was being taught, and I could bring about changes, such as instigating a move to allow the Fijian and Rotuman boys to speak in their native tongues, if they wished, instead of English during school hours. Also, I started questioning racial segregation in Fiji's schools, and I was bold enough in a staff meeting to suggest that Queen Victoria might want to consider Indian students worthy of its embrace. This sounded like heresy at the time and, needless to say, was not received with open arms. So the next best thing was to choose texts and topics in my English and history classes that dealt with issues of racial prejudice. One day I asked my students about their own attitudes. About half the class of twenty-five denied they were prejudiced against Indians. Then I posed the litmus test: "Would you consider marrying an Indian?" I was unprepared for the vehemence of their unanimous "No!" This was not a considered response to my question-it came from somewhere deep down in their guts. "No!"

It is unfortunate that Fiji's education system, particularly in schools such as Queen Victoria, Ratu Kadavulevu, and Adi Cakobau, did not teach Fijian students to see Indians as equals. Many of the major players in Fiji's politics today are former students of these schools. Sitiveni Rabuka, who carried out Fiji's first military coup in 1987, attended Queen Victoria, where I'm certain he excelled in the military training program. On the other hand, although I have little experience of what goes on in Indiandominated schools, I suspect that Fijian cultures and peoples are given little attention. The British, who brought the Indians to work the sugar plantations in 1879 , did not encourage the two races to intermingle. This attitude, as well as religious and cultural differences, partly explains not just the nature of the school system, but also why even after more than a hundred years, a marriage between a Fijian and an Indian in Fiji is as rare as a Fijian wearing a sari.

When the indentured laborers initially arrived in Fiji, their first sight of Fijians frightened them. According to Subramani, the Indians saw "these tall men of fine physique with upright hair and were reminded of the rashaks, savage people in Indian mythology. They felt superior to the Fijians, and called them hoos, a term that evokes savagery and lack of civilization" (1979, 3-4.) On the other hand, Asesela Ravuvu has revealed that the Fijians saw the Indians as "mean and stingy, crafty and demanding to the extent of being considered greedy, inconsiderate and grasping, 
uncooperative, egoistic and calculating" (I99I, 57). Further, the Fijians saw the Indians as potential thieves of their vanua or land. The term vanua refers not just to the land, but to the identity of Fijians as a people. Vanua embodies their worldview, their lifeline, their survival. Vanua embraces all animate and inanimate objects; thus, to lose their land would be to lose their identities as a people with a culture. The Fijian fear of the Indians, and the Indian fear of the Fijians, has not been eradicated, even in modern Fiji.

In July 2000 , when my wife and I drove from Nadi to Suva on a Sunday, we saw many well-dressed Fijians walking by the roadside, either on their way to or returning from church. The men wore white shirts with the formal wraparound (sulu) introduced by the early missionaries; the women wore long dresses that covered them down to their ankles. The vast majority carried bibles in their hands. Knowing we were headed to the capital where the hostages were still captive and a curfew was on, I wondered what role Christianity had played in the events of I9 May. I could not help but recall my experiences with the church in 1987, soon after the first coup. I went to church, thinking it would provide a safe haven from the racist remarks I was hearing everywhere I turned. But I was shocked to hear the Fijian minister at the pulpit refer to the Indians as evil heathens who needed steering to the Light, and proclaim that until they converted, they deserved to be treated as second-class citizens. I couldn't help but be reminded that when the first British missionaries came to Fiji, this was the way they spoke of the Fijians. That was an eyeopener for me. For years afterwards, I stopped going to church.

We all go through an idealistic stage when we think we can change the world. If you're a writer, you think your work can make a difference. And so in August of 1986, the Fiji Arts Club staged my play Sera's Choice in Fiji's capital, Suva. Sera is Fijian-her choice is to marry Anil, an Indian. Both Sera and Anil are graduate students at the University of the South Pacific, where they met. They've fallen in love, and despite opposition from their families, decide to marry. But before a year is up, the marriage begins to fall apart. The cultural and religious differences for these two idealists are too much for them. When Sera's sister Buna and her son from a village in Taveuni arrive in Suva and decide to make themselves comfortable in Anil and Sera's flat, Anil hits the roof-and Sera. He goes out to the seawall to think, but just after he makes up his mind to allow Sera's relatives to camp in their living room for a while, a group of Fijian men appear and beat him up. Blood dripping from his head, Anil returns home to find Sera and her sister Buna packing their suitcases. Anil asks Sera: 
ANIL: Why are you doing this to me? You cannot just walk out like this.

SERA: I can, and what's more, I'm leaving you NOW! Get out of my way.

ANIL: But why? Haven't I given you a roof and shelter? Hasn't there always been enough to eat in this house? Isn't this (indicating the house and its contents) good enough for you? (pause) Have you ironed my clothes?

SERA: They're in your drawer.

ANIL: And my shoes? I can't find my shoes.

(Sera quickly exits to the bedroom, returns and puts shoes in front of Anil.)

ANIL: Who's going to wash my clothes?

SERA: There's a board and scrubbing brush, Anil. You can do it.

ANIL: Oh, why are you leaving me? Haven't I given you all that a woman can want? You're all I have, Sera. And what about our child? Maybe when it's born our families will accept us.

BUNA (offstage): Sera? Are you coming?

(Sera pushes Anil away.)

SERA: That's my sister. Let me go ...

ANIL (very distressed): I need you, Sera. Are you coming back?

SERA: I don't know ...

ANIL: I'll change, Sera. I won't ever hit you again. And I'll be faithful to you. We'll have a proper life together. Please don't leave me.

BUNA: Sera?

(Anil moves to block the doorway.)

SERA: Let me go.

ANIL: Why are you leaving me? (pause) It's because I'm an Indian, right? Deep down you really hate me.

SERA: You know that's not true. I knew you were Indian when I chose to marry you.

ANIL: Then why?

SERA: Why? Why? You just don't understand, do you? Here I am, pregnant with your child, beaten up, and you stand there wondering why I'm leaving? Why don't you love me a little, show me I'm another human being, worthy of respect? Oh, why don't you make me part of you?

ANIL: I don't understand you.

SERA: No, you don't. You go around skimming the surface of life and you never try and understand me or the ways of my people. And you don't teach 
me to understand yours. I have abandoned my people but you won't let me become part of yours. I could have been something of both, Anil, but now I'm .... neither.

BUNA (offstage): Sera? Hurry up. I'm tired of waiting.

ANIL: Won't you please tell me where you're going so I could find you?

SERA: If you love me Anil, you'll find me.

(She exits. Anil closes the door and leans against it. He goes to the radio and turns it on: Fijian music. He tries to change it to the Hindi station but then changes his mind and goes back to the Fijian station. He sits down and listens attentively to the Fijian music for the first time.)

(Sera's Choice, I 52-1 53)

Nine months after Sera slammed the door on Anil and uttered those hopeful words, "If you love me Anil, you'll find me," Sitiveni Rabuka stormed Fiji's parliament and wrenched power from what was perceived as an Indian-dominated government. Although the prime minister, Timoci Bavadra, was Fijian, most Fijians viewed him as a puppet for Indian interests. Whether or not this was really the case is beside the point. As claimed by Rabuka himself, his coup was to protect Fijian interests from being usurped by a democratically elected government.

It's an understatement to say that those of us who were in Fiji during the first military coup were shocked. Nothing of the sort had happened in the peaceful Pacific before, and without a precedent, we had no guidelines on how to respond. We each did what we felt moved to do. While many of my colleagues were out on the street protesting and getting thrown in prison, I, coward that I am, started working on another play. Titled The Monster, this play was about two beggars: Ta, who is Fijian, and Rua, who is Indian. Having escaped from a shooting offstage, Ta and Rua discover a basket of leftover food. They fight over the contents of the basket and then decide that a more civilized approach to deciding who gets what would be to hand-wrestle. Being stronger and bigger, the Fijian beggar keeps winning, until the Indian asserts that the method of choice isn't fair and insists that they throw a coin. So they set up rules for this new method of deciding who gets the basket. The Indian beggar is the lucky one, and he wrests the basket away from the Fijian, who then, after disputing the Indian's honesty, calls upon his ancestral gods to come to his aid, and demands another toss of the coin. The Indian reminds the Fijian of the rules they had set up, rules that allowed him to win through fair and just means. The Fijian beggar reminds the Indian that he was the first to find 
the food basket. He insists on another election, I mean, another toss of the coin. Rua, the Indian beggar, replies sarcastically:

RUA: Until we get it right? No.

TA: To hell with the coin!

RUA: But the rules, it's all we have left. No rules, no justice.

TA: DON'T SAY THAT WORD AGAIN! I'LL KILL YOU IF YOU SAY THAT WORD AGAIN!

RUA: It's our only hope.

TA: There's no hope ... for you!

RUA (pause. Suddenly the truth dawns on Rua): Then I've been misled. I've been misled.

(Rua trembles in fear.)

RUA: I ... I ... Will you hold the basket for a while. I have to ... (Rua indicates she wants to throw up)

TA (patriotically): If I can help, I'm ready!

RUA: Thank you.

(Rua hands over the basket and turns her back to the audience. She clutches her stomach in agony.)

TA (making a speech): If my help is needed at a time of crisis, I shall give it. How can I stand idly and watch while my sister...

(Ta suddenly jumps on top of Rua. They struggle, with the basket left alone at center stage. During the struggle, a monster appears and heads towards the basket. The monster is enormous, ugly, multicolored and horrible! When Ta and Rua realize that their lives are in danger, they forget their differences and attack the monster. After a lot of struggle, the monster is killed. Exhausted, Ta and Rua stare at each other as a transformation comes over them. Their bodies relax, the frowns disappear to be replaced by radiant faces.)

RUA: We've killed the monster!

TA: I feel different.

RUA: Something's changed in me. I don't understand.

тA: Neither do I. (pause) We've killed the monster!

(They look at each other fondly and shake hands. Then they pick up the basket of food, place it between them and feed each other.)

(The Monster, I I I-I I 2) 
Just before we were to stage this play at the University of the South Pacific, a second coup took place, and the military passed a decree that all creative expression was banned. The army had checkpoints on the roads to and from Suva, and my cast feared for their safety. But we decided the show must go on. Soldiers were positioned just outside the campus gates when we exercised our right to free expression, and I was told there were policemen in plainclothes in the audience. Why we weren't arrested remains a mystery to me.

An Indian colleague accosted me at the end of our performance to tell me that my play was unrealistic and idealized. The monster is still running around wreaking havoc out there, he pointed out. He had interpreted the monster as Rabuka, whereas I had intended the monster to be a physical manifestation of the evil in all of us. Specifically, the monster is our racial prejudice. It can also be our fear and distrust of the other. In this play, I'm saying that unless we kill this monster-this fear, this distrust of the other-we will never be able to live in harmony. The next best solution, if we're unable to kill our monster, is to have rules imposed on us. This is what the Indian beggar keeps harping about: no rules, no justice, he says. However, the Fijian's response is: "I'll kill you if you say that word [rules] again!”

The only time during the play when Ta and Rua cooperate and work together to achieve a common goal, the only time when they seem to be working with each other instead of against each other, is when a third party, in this case the monster, threatens to annihilate them. This reminds us that when the British (dare I say a monster?) ruled over Fiji from I 874-1970, there was relative stability in the country. Seventeen years after the British had left, Fiji experienced its first military coup. What does this say about us? That we all need a third party to make us behave? That we all need an external force to keep law and order? For Fiji, is this external force the constitution? Which constitution?

After the last election (1999), when I heard that Mahendra Chaudhry had been chosen as Fiji's first Indian prime minister, I was incredulous. Although I had moved from Fiji to Hawai'i ten years ago, I have kept close ties with Fiji, and I could not believe that the Fijians were ready to accept an Indian prime minister. I remember telling my students it was a miracle that Fiji's choice of an Indian prime minister had not led to civil war. I thought it a sure sign that Fiji had come of age, that it could now reclaim that famous slogan that made all of us Fiji citizens very proud in the seventies and early eighties: "Fiji, the way the world should be!" I wanted so 
much to believe that Fiji had killed its monster, and accomplished a transformation in relations between Fijians and Indians. Now I realize that harmony in Fiji was possible for a short while only because Fijians honored the rules, the 1997 constitution.

Fijians, like most people who come from oral societies, have a healthy distrust of the written word (Ravuvu I99I, ix). In the late nineteenth century, Alfred St Johnston, in a book titled Camping Among the Cannibals, stated that when the Fijians saw him write quickly on a piece of paper and then read aloud to them, they were much amused (I 883, 243). Similarly, St Johnston reported that when a Tongan first saw William Mariner write down his name, "Feenow," on paper and heard him read it out loud, the Tongan exclaimed, "This is neither like myself, nor anybody else; where are my eyes, where is my head, and where are my legs? How can you possibly know it to be I?" (St Johnston I 883, 243) Pacific Islanders know that the written word is a foreign flower; they know that the written word, at least in the constitution, is not in their own language (why it isn't written in Fiji Hindi or the Fijian language I don't understand); and they know that the people who wrote those rules that they are supposed to follow are powerful people who do not necessarily take into account the interests of those who can barely read or write. They know that power can corrupt. But they hope that those who made those rules, and those who have come to power because of those rules, will be fair and just in their dealings with them. And they wait and see. When the evidence before them suggests their leaders no longer care about them-or have defected to the opposing camp - they figure out a way to restore justice. This is a very human impulse, and one that all of us can relate to.

For some cultures, the intellect seems to be the most important means of knowing what is or is not the truth. Often, those of us who come from oral cultures rely on our intuition to guide us. Konai Helu Thaman, a leading Pacific intellectual of a different kind, captures this difference eloquently in her poem, "Our Way" (see Thaman, this issue, 3-4).

Apart from a strong distrust of the written word, many Fijians have a strong distrust of Indians. Thus we can assume that when an Indian prime minister came into office in $\mathbf{1 9 9 8}$, he was observed very closely by the Fijian population, most of whom neither lived in the city nor were fully versed in the intricacies of the constitution. Had an Indian prime minister of great sensitivity to Fijian concerns been chosen to lead, I believe events in Fiji could have turned out differently. But instead we got the equivalent of an arrogant chief, perceived by many as not only non-Fijian but anti- 
Fijian. George Speight's storming of parliament is a modern replay of the Fijian way of dealing with arrogant chiefs. Asesela Ravuvu, in his book The Façade of Democracy, stated that "the chief who did not adequately care for his followers could instigate his own destruction by those who were not happy with his rule, or by someone else whose assistance they requested through offerings and gifts" (Ravuvu I99I, 2).

Mahendra Chaudhry's style of leadership was illustrated in the wellpublicized case of Fiji's lucrative mahogany forests-another British experiment, which began in the I950s and I960s. Chaudhry made decisions that may have made sense to him, but to the average person appeared irrational and anti-Fijian. How was the rural villager on whose land the mahogany trees grew to make sense of this: the "preferred bidder" - a British concern with a forty-year track record in Fiji-valued the mahogany at $\$ 65$ million, while the "rejected bidder"-a Seattle-based real-estate developer with links to George Speight—offered \$2 Io million. If we are to believe the New York Times, Chaudhry "needed the backing of Fiji's former colonial patron in negotiations with the European Union over export supports for sugar," Fiji's leading industry, and a business dominated by ethnic Indians (Kahn 2000, 8). Given the delicate nature of Fiji's identity politics, Chaudhry might have been expected to tread very slowly and carefully. He might have consulted the landowners themselves, explained to them his views, and sought their support. But feeling secure that the constitution protected him, Chaudhry remained aloof, distant. Meanwhile, George Speight was cultivating the support of these landowners, explaining to them his side of the story, drinking kava with them, and acting like he was one of them. Of course we now know that Speight was "fanning landowner discontent for his own purposes"(Kahn 2000, 8) and that he had other motives, but should it surprise us that the landowners sided with Speight?

In late March 2000, some I0,000 indigenous Fijians marched through the streets of Suva, calling on the government to stop making decisions on two key land issues: the mahogany, and the renewal of leases on land used to grow sugar cane (Kahn 2000, 8). On I9 May, 20,000 landowners marched through the streets again, and some marchers destroyed businesses run by ethnic Indians. Meanwhile, George Speight and seven paramilitary troopers, in a four-wheel-drive jeep, stormed the parliament building, captured Chaudhry and his cabinet, and held them hostage for two months. 
Many of us are familiar with the wisdom in Epeli Hau'ofa's collection of short stories titled Tales of the Tikongs. It should be required reading for every government official and developer in the Pacific. Unfortunately, the people who should be reading this remarkable work are too busy trying to develop our islands. If they were to read just one of the stories in this collection titled "The Tower of Babel," they would learn a secret that would stop military coups in the Pacific forever. In this story, they would learn that development for small Pacific Islands will not work unless the culture and the people concerned are taken into account. Too often the focus is on an idea or an ideology, and the ordinary folks who should matter the most are marginalized in the decision-making process. Fijian landowners need to be respected; they should have been consulted on matters pertaining to their lands. Marching the city streets in the hope that their voices would be heard was unbecoming to the dignity of older Fijian men who had allowed the use of their lands so that the Indians might prosper and enjoy the comforts of the city. Surely Fijian landowners deserved better treatment from Mahendra Chaudhry's government.

It is false security to think that a new constitution will ensure there will be no more military coups in Fiji. Democracy is a foreign flower, as we have heard from the lips of Fijians. We should take heed. What are the alternatives? Sitiveni Halapua, that sage of the East-West Center, should be listened to more often. He was right when he said that the present form of democracy in Fiji (and the Solomons as well) "is highly inappropriate to the cultural settings of these countries"; he warns us that Fiji's rural folks do not "really recognize the authority of the central power of government" (quoted in Yim 2000). Why should they, when they see the city folks becoming richer and richer and the rural folks becoming poorer and poorer? Why should they, when their chiefs, traditional or modern, have no time to sit down and have a bowl of kava with them anymore? This growing chasm, not only between Fijians and Indians but among Fijians themselves, is at the heart of the challenge and cries out for answers.

One of the important lessons for Fiji as a result of the recent coup is the awareness that Fiji's rural people, as well as the urban dispossessed, are an untapped source of political power. Dissatisfied with their lot, they are vulnerable to manipulation by the likes of George Speight. Claiming that his actions were carried out in the name of the vanua, he seemed able, over time, to gather the support of the majority of Fijians. Pio Manoa, a Fijian academic at the University of the South Pacific, has warned us to be dis- 
cerning, for many voices are out there claiming to represent the people. He labeled this "the new paternalism"- - voices that claim to be the voice of the people but in the end misrepresent the people. Many of these people "have influence and live in affluence at the cost of the ordinary people" (Manoa 1988, 274). But how do we tell which voices are authentic when there are so many, all claiming to represent the vanua or the people?

The Fijian people do not speak with one voice. There are factions within the community, some caused by traditional tribal affiliations, others by the vast differences that separate the urban middle class from their rural counterparts. It is no longer credible to claim to represent the rural masses while living a life of affluence in the city. Our challenge is to be able to recognize the fake from the real, and to question the claims to authenticity of any new leader.

Manoa suggested that for a voice to be authentic, it must "become the voice of the people feeling in a new language" $(1988,274)$. Both Rabuka and Speight appeared to have widespread support among the Fijian people because they claimed to be "the voice of the people." Both have maintained that their actions were motivated by the Fijian people's perceived fears of losing their land and resources, and in both instances, masses of rural people were mobilized. It is now apparent that the country's leaders can no longer ignore the marginalized people of Fiji, for they pose a real threat to the leaders' political survival. Makiuti Tongia of the Cook Islands wrote about this real threat in his poem:

As I walk this rich suburb

full of white and black chiefs

I hear the barking of a dog

I listen to its calls

knowing I am that dog

picking what it can

from the overflowing rubbish tins

I say to you chiefs

bury the scraps you can't eat

So no hungry dog will come to eat

at your locked gate

Chiefs beware of hungry

dogs!

(Makiuti Tongia, "Beware of Dog”) 
How then do we separate the voices that are authentic from the ones that are not? By their deeds, said one sage, by their deeds will we know them.

One of the most powerful ways Fijian leaders appeal to the masses is by asserting that their deeds are carried out so that the vanua will remain in Fijian hands. Such assertions never fail to evoke deep-seated fears, which often appear irrational because Fijian land is protected under the constitution. Since independence in 1970, Fiji has had its share of die-hard nationalists whose rhetoric can be very appealing to the poor, looking for scraps to eat. When people are desperate, they will often behave in ways that do not serve their long-term interests. Brij Lal, one of the architects of the 1997 Constitution that has been rejected by Fiji's interim administration, has noted, "Fijians have shown that when push comes to shove, their loyalty is to the vanua, to the chiefs, not to the institution of the army" (Hereniko 2002, I80).

Future leaders of Fiji will have to address this deep-seated fear on the part of Fijians, and must unmask any attempts by present and future leaders to exploit the confused emotions of the people for personal gain. This is one of the most difficult tasks facing all of us, whether we be poets or academics with an interest in finding solutions to Fiji's problems. Second, future leaders must build trust between its peoples, both Fijian and Indian. Last but not least, respect for the written word-and by extension, respect for authority, elders, and each other-must be fostered, so that the rules of the new game, as spelled out in a new constitution, will be honored.

My hope is that a new constitution will further adapt democracy to make it more compatible with Fijian culture. It is unrealistic to expect the Fijians who have practiced communalism for over a century to adapt overnight to a democratic system of one person, one vote, without any hiccups. Given the factions within Fijian society that have become apparent since I9 May 2000, decentralization of power appears to be worth considering. Perhaps a model such as that employed by the University of the South Pacific, in which there are various centers throughout the region, is one that Fiji might consider for its more than three hundred islands under the sun.

The wounds of the Indian population must be healed at the same time. It is imperative that Indians learn to understand the Fijian fear of one day losing their land. And Fijians must come to understand Indian feelings of insecurity in the land of their birth. In short, both communities need to understand what makes the other tick. With understanding, acceptance 
will come more easily. As a Rotuman who is often caught in the middle of tensions between Fijians and Indians, I have a stake in wanting a stable political climate. Without a stable situation in Fiji, Rotuma might have to reconsider its present relationship and seek more autonomy so that it will be able to function unhampered by Fiji's internal conflicts. Maybe it would be a good thing for Rotumans to become more political and seek their independence. Or perhaps an economic crisis would force Fijians and Indians to realize they need each other to survive. After all, their lives are inextricably intertwined and inseparable. I hear that an education commission has been formed that is likely to recommend sweeping changes in the education system. Maybe our hope lies in a new generation of Fijian and Indian children who will learn to trust each other because they live and work together in the same neighborhoods and the same schools.

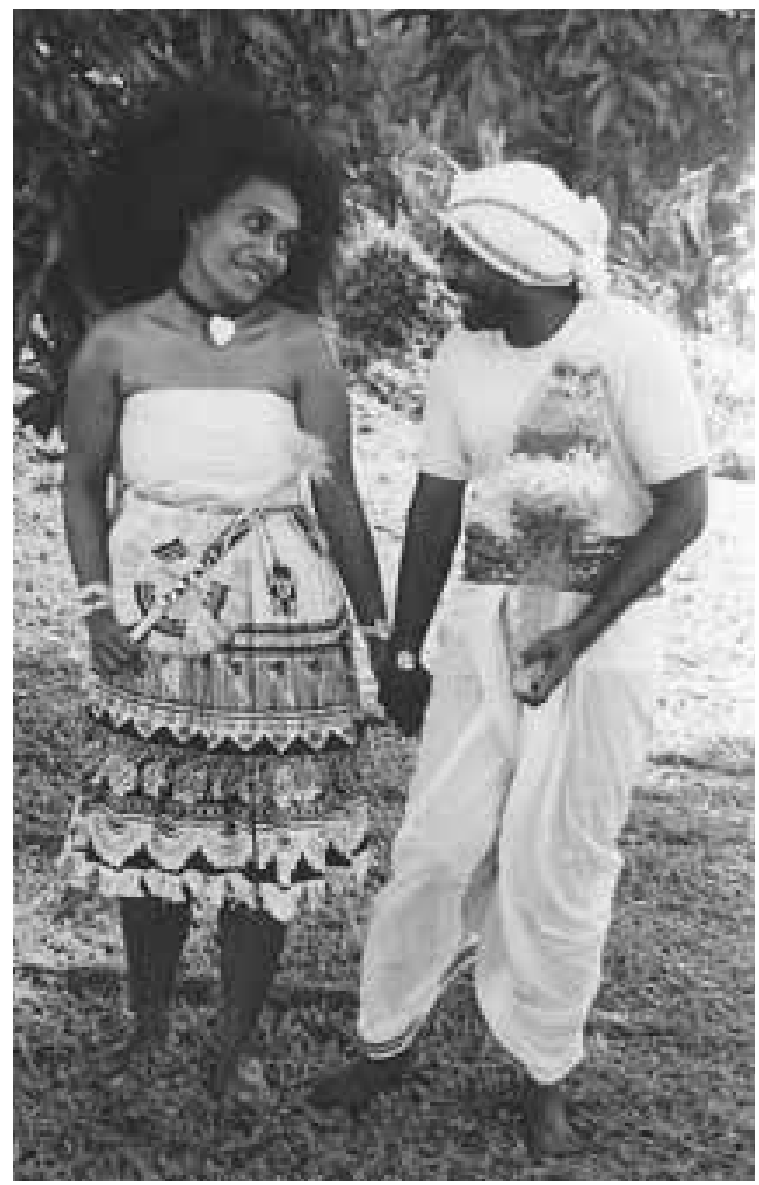

Photo by Litiana

Waqalevu, I987 
I have a dream for Fiji. I dream that all Fiji's schools are multiracial, and all the students are taught at least English, Fijian, Hindi, and Rotuman. In the same dream, I'm an invited guest at a marriage ceremony where the bride's name is Sera, and the husband's Anil. Yes, because of his love for Sera, Anil has finally found her. To hold on to this dream, I have a picture of an Indian man and a Fijian woman-actors in one of my plays-both dressed in traditional costumes, holding hands, and admiring each other. This picture has had a prominent place in my office wall for the past twelve years, ever since I moved to Hawai'i. I hope one day this dream will come true.

\section{References}

Hau'ofa, Epeli

I994 The Tower of Babel. In Tales of the Tikongs. Auckland: Longman Paul, 1983. Reprint, Honolulu: University of Hawai'i Press, Talanoa Series, I 8-26.

Hereniko, Vilsoni

I987 Sera's Choice. Suva: Mana Publications.

I989 The Monster. Suva: Mana Publications.

2002 From the Sideline: An Interview with Brij V Lal, Historian and Constitutional Commissioner. The Contemporary Pacific I4: I68-1 84.

Khan, Joseph

2000 The Mahogany King's Brief Reign: Business Interests Lurked Behind Fiji's Haphazard Coup. New York Times, I4 September, final edition, section C, I.

Manoa, Pio

I998 Singing in Their Genealogical Trees. In LL I02: Pacific Literature in Eng-

lish: Introduction and Assignments, Semester 2, by Subramani. Suva:

University of the South Pacific, 269-276.

Ravuvu, Asesela

I99I The Façade of Democracy. Suva: Reader Publishing House.

St Johnston, Alfred

I 883 Camping Among Cannibals. London: Macmillan \& Co.

Subramani

1979 The Indo-Fijian Experience. St Lucia: University of Queensland Press.

Tongia, Makiuti

I977 Beware of Dog. In Korero, I I. Suva: Mana Publications.

Yim, Susan

2000 Asia Pacific Security Outlook 2000: Region is at Crossroads. Observer 4 (3 [Summer]): 9. Honolulu: East-West Center. 


\section{Abstract}

The reasons behind Fiji's military coup of I9 May 2000 are complex, and cannot be fully understood on a purely rational or empirical level. An interdisciplinary approach that embraces culture and history, informed by fiction, poetry, and drama, as well as personal experience, offers insights into Fijian-Indian relations. In this paper I explore the nature and usefulness of the interdisciplinary process in helping to make sense of a specific event in Fiji's history; I also seek to better understand the guiding principles that might inform future interdisciplinary research and writing. This does not mean that the approach here is necessarily applicable to understanding other similar events or topics. My primary goal is not to lay down principles set in stone but rather to stimulate discussion and debate on interdisciplinary approaches to Pacific studies.

KEYWORDs: coups, interdisciplinary process, Fijians, Indians, George Speight, racial prejudice 